\title{
Geomorfološke značilnosti Tržaškega zaliva in obrobja
}

\author{
Milan Orožen Adamič \\ Dr., Geografski inštitut Antona Melika, Znanstvenoraziskovalni center SAZU, \\ Gosposka 13, 1000 Ljubljana, Slovenija \\ e-mail: milan@zrc-sazu.si
}

\section{Izvleček}

Tržaški zaliv je plitvo robno morje, skrajni severni del Jadrana, ki je s treh strani omejen s kopnim. Ker je v njem razmeroma malo vode, manj kot v kakšnem velikem jezeru je izjemno občutljiv na ekološke spremembe. Geomorfološka dejstva nas opozarjajo na to, da so možnosti rabe zelo omejene. $V$ prihodnje bo potrebno zelo skrbno, pretehtano in uravnoteženo ravnanje z naravnimi danostmi. Danes se zdi, da se ob umanjkanju dolgoročne razvojne vizije tega ne zavedamo dovolj.

Ključne besede: podvodni relief, morje, Tržaški zaliv, Slovenija

\section{Geomorphological Features of the Bay of Trieste and its Shore}

\begin{abstract}
The Bay of Trieste is a shallow marginal sea, the northernmost part of the Adriatic Sea surrounded by land on three sides. As it contains relatively little water, less than some large lakes, it is extremely sensitive to ecological changes. The geomorphological facts warn us that the possibilities for its exploitation are very limited. In future, a very careful, thoughtful, and balanced approach to dealing with its natural resources will be essential. Given the current lack of any long-term developmental vision, it appears that we are not sufficiently conscious of this fact.
\end{abstract}

Key words: underwater relief, sea, Golf of Trieste, Slovenia. 
Tržaški zaliv je najsevernejši del Jadrana in obsega približno $570 \mathrm{~km}^{2}$ (Radinja 1990). Po meritvah Geografskega inštituta Antona Melika ZRC SAZU s pomočjo pomorske karte je nekoliko manjši $548 \mathrm{~km}^{2}$. Ta približno $5 \%$ razlika in je možna zato, ker široko ustje, vhod v Tržaški zaliv, ni točno določeno. Sicer pa Tržaški zaliv obsega le $0,4 \%$ akvatorija Jadranskega morja in je obenem njegov najbolj severni, torej najbolj roben del Sredozemskega morja. V geografski literaturi ga običajno obravnavamo kot samostojno naravnogeografsko enoto, kot posebno naravnogeografsko pokrajino, ki ima vse značilnosti mezoregije. Od slovenskih geografov ga je prvi podrobneje opisal Anton Melik (1960). V regionalnem opisu slovenskih pokrajin v knjigi o Primorski Sloveniji je Tržaškemu zalivu, seveda z obrobjem, namenil več kot tri petine knjige. Morfološkim in fizično geografskim značilnostim Tržaškega zaliva pa je posvetil (Melik 1960) več kot 40 strani. V uvodu v to knjigo je Melik, za geografa tako značilno, zapisal $(1960,5) » P r a v$ ob morju je tedaj sorazmerno majhen del slovenske zemlje. Toda dih morja sega mnogo bolj daleč, učinki blagodejne bližine morja se raztezajo bolj na široko $v$ bližnje zaledje. In za vse to ozemlje se je vživi ljudski govorici že od nekdaj uporabljala označba primorsko ozemlje.« To, da je Tržaški zaliv posebna naravno-geografska pokrajina, torej ni posebnega dvoma. Njegova omejitev z vodno črto, stikom morja s kopnim, je $\mathrm{v}$ primerjavi $\mathrm{z}$ drugimi naravno-geografskimi regijami nenavadno natančna. Obalna črta Tržaškega zaliva je dolga približno $130 \mathrm{~km}$, kar je skoraj dvakrat več od zračnih razdalj stranic zaliva. Zato, ker je povezava med kopnim in morjem tesno med seboj povezana je stvarno in smiselno, da obravnavamo tudi neposreden obalni svet. To obrobje je z zalivom, $\mathrm{v}$ mnogih pogledih, tesno prepleteno in »organsko« povezano. Ob lepem vremenu, po kakšni burji, ki navdano razpiha ozračje, $z$ dobre razgledne točke, ga lahko s prostim očesom zaobjamemo v celoti. Taka, morda najbolj znana, razgledna točka je vzpetina na kateri stoji cerkev Sv. Jurija, ki kraljuje nad Piranom. Če sledimo razmišljanjem tudi drugih, ki so pisali o tem delu Slovenije, je Tržaški zaliv nekakšna »izvorna«, temeljna, osnovna pokrajina, podobno kot visokogorje Julijskih Alp, široke nižine Panonskega sveta ali visoke kraške planote Dinarskega sveta. V stran od »izvornih « pokrajin se postopoma vedno bolj uveljavljajo vplivi drugih pokrajin. To je za Slovenijo je to še posebej značilno, ker imamo v naših naravnogeografski regionalizacijah opravka s široko paleto in izjemno pokrajinsko pestrostjo, ki se še posebej zrcali v najrazličnejših prehodnih pokrajinah. Prav to je, morda najbolj, izstopajoča naravno-geografska značilnost Slovenije.

Ob tem je seveda dejstvo, da ima Tržaški zaliv, z njim pa tudi slovensko morje bolj kontinentalne kakor izrazito maritimne značilnosti, ker je podvržen izdatnemu temperaturnemu kolebanju, kar za večja morja seveda ni značilno. To je nedvomno ena njunih najznačilnejših celinskih potez. Ker se morje po- 
leti močno segreje (do $26^{\circ} \mathrm{C}$ in več), pozimi pa precej ohladi $\left(\right.$ do $9^{\circ} \mathrm{C}$ ), v tem pogledu je ekstremni del Jadrana (Bernot 1990).

Danes si Tržaški zaliv med seboj delijo tri države Italija (65\%), Slovenija (32 \%) in Hrvaška (3 \%). Pri tem pa pomeni 47,6 km Slovenska obale manj kot tisočino dolžine celotnega obrežja Sredozemskega morja (Radinja 1990). Zračna razdalja od državne meje z Italijo pri Lazaretu do meje s Hrvaško na Dragonji je dolga le nekaj več kot $17 \mathrm{~km}$.

Presenetljivo je, da regionalnogeografskih opisov Tržaškega zaliva ni veliko, še posebej, če jih primerjamo z besedili o našem visokogorju ali pa tudi drugih delih Slovenije. Razlog za to je morda v tem, da je to posebna morska pokrajina, ki se jo ni razumelo kot samostojno naravnogeografsko regijo. Med celovite preglede, poleg Melikovega opisa (1960) lahko uvrstimo le še poglavje o Tržaškem zalivu (Orožen Adamič 1998, 1999, 282-291) v knjigi Slovenija pokrajine in ljudje $(1998,1999)$. Na 15. zborovanju slovenskih geografov, ki je bilo v Portorožu (1990) so o Tržaškem zalivu v duhu samostojne pokrajine razpravljali Radinja (1990a, 1990b), Orožen Adamič (1990) in Bernot (1990).

Tu se s Sredozemljem stikajo Dinaridi in prav blizu so tudi Alpe. Ob prvi značilnosti Tržaškega zaliva, da je to razmeroma majhno območje je njegova druga in še pomembnejša geomorfološka značilnost, da je povprečna globina morja v njem le 16,4 m. Manj kot polovica zaliva je globoka okrog $20 \mathrm{~m}, \mathrm{v}$ manj kot sedmini zaliva so globine od 10 do $15 \mathrm{~m}$ in več kot petina zaliva je plitvejša od $10 \mathrm{~m}$. Le malo kje je Tržaški zaliv globlji od $25 \mathrm{~m}$, danes pa imajo največje tovorne in potniške ladje grez tudi od $14 \mathrm{~m}$. Zato so morali pristanišče Koper poglobiti in izkopati »jarke« v sedimentno dno s posebnim kopačem (bagerjem). Izkopan material so odlagali na del obale od pristanišča proti Ankaranu. Potrebna so stalna vzdrževalna dela. Zaradi opisane podvodne reliefne morfološke izoblikovanosti je količina vode v Tržaškem zalivu razmeroma majhna in to le okrog $9 \mathrm{~km}^{3}$, kar je manj od marsikaterega večjega jezera. Radinja (1990) je volumen morja v Tržaškem zalivu ocenil na $11 \mathrm{~km}^{3}$, kar pa se je ob boljšem poznavanju morfologije dna pokazalo za nekoliko pretirano. Vse to se odraža tudi v precejšnjih in razmeroma hitrih nihanjih temperature morja ter občasnih, hitrih, da, celo velikokrat dramatičnih spremembah lokalnih ekoloških razmer. Ker je zaliv iz treh strani obdan s kopnim in je vhod vanj z morske strani na črti Savudrija-Grado (Gradež) širok le približno $21 \mathrm{~km}$, so v njem opazne kontinentalne poteze in ravno te hitre spremembe, ki se kažejo tudi v njegovi ekološki razmeroma veliki ekološki občutljivosti (Štirn 1970).

Potek 20-metrske izobate v smeri od jugozahoda proti severovzhodu loči "zunanje", odprto morje v osrednji kadunji (78 \%) od "notranjega", priobalnega morja (18\%). Slovensko priobalno morje sestavljata v bistvu le dva večja zaliva, Koprski in Piranski. Pomembna sta še dva manjša zaliva, na obeh stra- 
neh najbolj slikovitega in koničastega piranskega polotoka, Strunjanski in Portoroški. Vsi drugi zalivi so precej manjši in manj globoko vrezani v kopno.

Grafikon 1: Deleži globinskih pasov Tržaškega zaliva (vir: Geografski inštitut Antona Melika 1998).

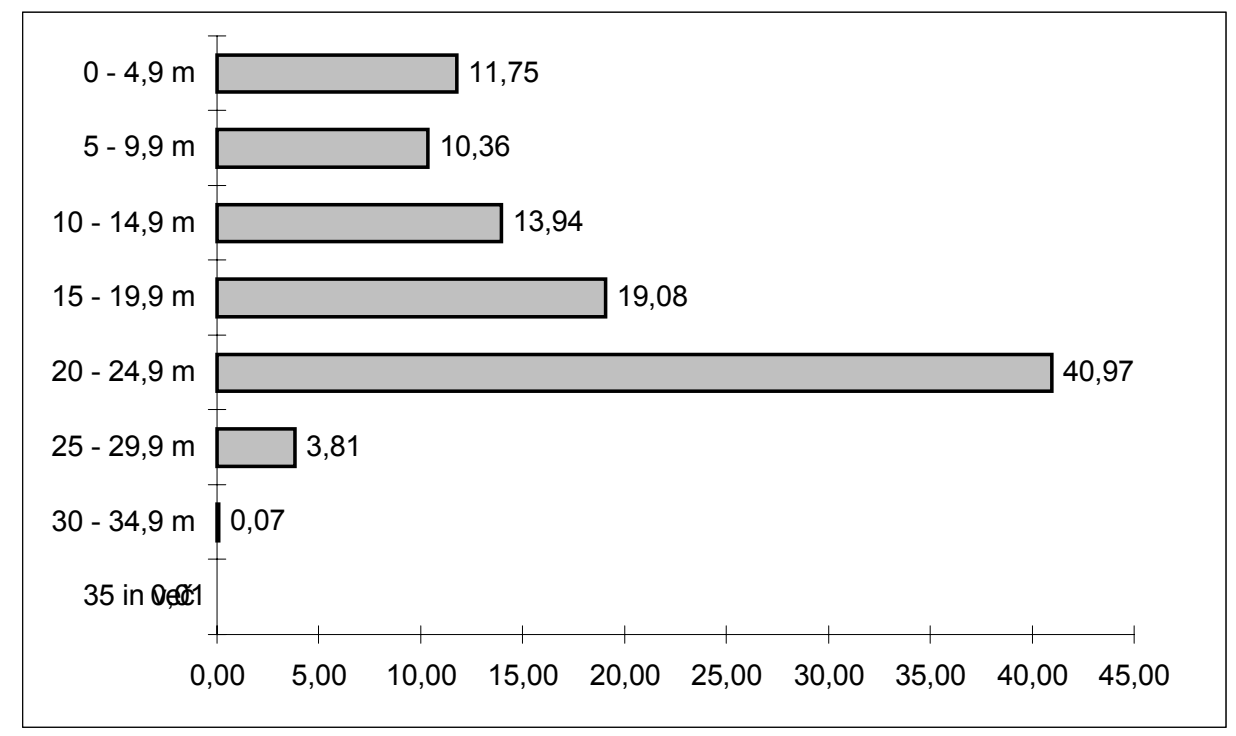

Če bi voda odtekla, bi se pred nami pokazala skorajda ravna, blago usločena konkavna kadunja, ki se na robovih počasi dviguje. Osamljenih skalnih plitvin, otokov, čeri ali podmorskih grebenov v slovenskem, kakor tudi v obče $\mathrm{v}$ Tržaškem zalivu ni. V podvodnem površju ni večjih izstopajočih morfoloških oblik. Če bi se morje umaknilo, odteklo bi se pred nami razprostrla na oko skorajda ravna, lahko bi rekli monotona površina. So pa izjeme, kot je kotanja največje globine zaliva pri Piranu in v zadnjem času odkriti podvodni izviri pri Izoli o katerih je na tem zborovanju poročal Jože Žumer.

Osrednji del morskega dna (98 \%) pokrivajo najrazličnejši marinski sedimenti, ki so večinoma zelo drobno zrnati in se razlikujejo po velikosti delcev, ki jih sestavljajo. Sedimentacijo, za nas najbolj zanimivega, Piranskega zaliva je prvi podrobno raziskoval Ranke (1974) in njegove ugotovitve kažejo, da so sedimenti bliže obal praviloma finejši. Gre torej za različne tipe sedimentnega dna, ki pa imajo večinoma značilnosti muljevitega dna in drobnih peskov. Ob apneniških obali je delež peska v sedimentnem dnu priobalne podvodne terase večji kot ob flišnih obali. 
Preglednica 1: Površine in deleži posameznih globinskih pasov Tržaškega zaliva (vir, Geografski inštitut Antona Melika 1998).

\begin{tabular}{|l|r|r|}
\hline Globinski pas & $\mathbf{k m}^{\mathbf{2}}$ & $\mathbf{\%}$ \\
\hline $0-4,9 \mathrm{~m}$ & 64,435 & 11,750 \\
\hline $5-9,9 \mathrm{~m}$ & 56,811 & 10,360 \\
\hline $10-14,9 \mathrm{~m}$ & 76,461 & 13,944 \\
\hline $15-19,9 \mathrm{~m}$ & 104,649 & 19,084 \\
\hline $20-24,9 \mathrm{~m}$ & 224,668 & 40,971 \\
\hline $25-29,9 \mathrm{~m}$ & 20,903 & 3,812 \\
\hline $30-34,9 \mathrm{~m}$ & 0,391 & 0,071 \\
\hline 35 in več & 0,044 & 0,008 \\
\hline Skupaj & $\mathbf{5 4 8 , 3 6 2}$ & 100,000 \\
\hline
\end{tabular}

Neposredni obalni pas, razen v območju sedimentnih akumulacijskih obal kjer sega ta prav do obalne črte, sestavlja pod vodo različno široko območje tako imenovanega trdnega "skalnega" dna. Točne površine tega trdnega skalnega dna ne poznamo, ker doslej še ni bila podrobno kartiran, ocenjujemo pa, da obsega je manj kot $2 \%$ podvodnega površja Tržaškega zaliva. V prihodnje bi ga bilo koristno kartirati, ker je to brez dvoma posebno pomemben življenjski ekološki prostor, substrat, ki ga je malo in je zaradi najrazličnejših posegov kot je zaradi antropogenega zasipavanje priobalne ravnice resno ogrožen. Zato so se pojavile tudi pobude (Ugo Fonda) o izgradnji umetnih podvodnih "grebenov«, ki naj bi povečali površino trdnega skalnega dna, ekološki prostor za življenje na tem substratu. Največji del neposrednega trdnega priobalnega sveta v Sloveniji zavzemajo območja s flišem, kot prevladujočo kamninsko obliko, preperelino laporja in peščenjaka. Dominantna značilnost tega tipa obale se kaže nad morjem in obalno črto z izrazito abrazijskim tipom obale, ki se slikovito nadaljuje $\mathrm{v}$ strmih klifih. Klifi so mestoma 100 in več metrov visoki in so najvišji v tej kamnini na Jadranu (Gams 1970). Na mestih, kjer pritekajo v morje manjše reke ali potoki, se je zaradi nanašanja drobnega gradiva, izoblikovala bistveno drugačna obala, ki jo navadno označujemo za akumulacijski tip obale. V Sloveniji, pa imamo le pri Izoli, kjer sega neposredno do morja manjšo kraško apneničavo zaplato in tako opravka s kraškim podvodnim priobalnim svetom. Tako podvodno površje je tudi ob vznožju Tržaškega Krasa v današnji Italiji segajo zadnji odrastki Krasa do morja. Ta severovzhodni del obale Tržaškega zaliva se razteza $\mathrm{v}$ razmeroma ravni in značilno dinarski smeri. Pri Miramaru, kjer je na vodni črti tudi nekaj kraških jam, spodmolov in drugih kraških oblik, kot so na primer vrulje (Brojnica/Aurisiana). Tak tip obale je najbolj na široko razširjen in običajen vzdolž vzhodne 
obale Jadrana. Začne se pravzaprav že v Piranskem zalivu, na levi strani regulirane struge Dragonje in nadaljuje naprej prek polotoka Savudrija v Istro in Dalmacijo.

Soča je največja reka, ki se izliva v Tržaški zaliv. Jugozahodno, med izlivoma Soče in Tilmentom (it. Tagliamento) je obsežen sistem priobalnih plitvin, ki ga sestavlja sistem lagun, kakršnih v slovenskem priobalnem svetu ne poznamo, Gradeška (Laguna di Grado) in Maranska laguna (Laguna di Marano). Večja od teh je le Beneška laguna (Laguna Veneta), ki je okoli $50 \mathrm{~km}$ bolj jugozahodno. $\mathrm{V}$ območju lagun in priobalnih plitvin se je razvil tudi poseben tip ribolova, pri delu so si pomagali z lokalno razvito posebno obliko čolna z ravnim dnom, ki ga imenujejo batana. Danes so lesene batane na vesla skorajda izginile. V Koprski zaliv pritekata Rižana in Baševica, v Strunjanskega Strunjanski potok ter v Piranski zaliv Fazan, Jernejski potok, Drnica in Dragonja. Vse te vode, ki imajo obsežno in večinoma lahko erodibilno flišno zaledje in plavijo v morje velike količine gradiva. Ker pa imajo vse te vode tudi občasno zelo hudourniški značaj, tudi poplavljajo (Orožen Adamič, 1980; Plut, 1980). Glede na velikost posameznega pritoka se je postopoma oblikovala večja ali manjša plitva aluvialna holocenska ravnica. Ti plitvi deli obale so že stoletja izjemno močno preoblikovani in izredno intenzivno »obdelani«, kjer so najpomembnejše solina, $v$ zadnjih letih pa najrazličnejše marikulture (klapavice, ostrige, orade, brancini in podobno). Danes so mnoge površine nekdanjih solin opuščene, zasute in uporabljene v povsem druge namene, na primer Marina v Portorožu. V tradicionalnih solinah so bile vse dejavnosti podrejene sozvočju z morjem in spopadanju s silami narave. Najbolj nevarna je bila uničujoča kombinacija rečnih in morskih poplav. Najprej so opustili soline pri Kopru, ki je bil nekdaj otok, soline pri Izoli, po 2. svetovni vojni pa soline pri Luciji in del solin v Sečovljah. Deloma so regulirali Rižano, Badaševico, Dragonjo in Drnico. Vendar vsa ta prizadevanja spočetka niso dala pričakovanih rezultatov, ker so posvečali premalo pozornosti hidrografskemu zaledju - notranjosti in so bili vsi ukrepi izrazito usmerjen na razmeroma ozek obalni pas. V notranjosti je prišlo do razmeroma hitrega zaraščanja, opuščanja gojenja kultur na terasah in $\mathrm{s}$ tem tudi do zmanjšanja hudourniškega značaja vodotokov (Orožen Adamič 1980). Do intenzivnejše izrabe notranjosti, tudi revitalizacije kmetijstva, ponovno prihaja šele $\mathrm{v}$ zadnjih letih.

$\mathrm{Ob}$ apneniških in flišnih obalah spremlja obrežni podmorski pas živoskalno dno, ki se v številnih manjših terasah, ki jih je omenil že Šifrer (1965) pod vodo spušča $\mathrm{v}$ rahlem naklonu do globine med 8 in 10 metri. $\mathrm{V}$ tej globini $(9 \pm 1 \mathrm{~m})$ je izrazit pregib s strmejšim skokom, ki sega vse do sedimentnega dna. Prav ta skok ali „rob” (to ime se je uveljavilo med potapljači) je najbolj slikovita oblika $v$ tem tipu podvodnega obalnega reliefa. Naklon tega str mejšega spusta, ki ima ponekod celo značaj manjše stene, je lahko tudi do $70^{\circ}$ 
Slika 1: Podvodni Triglav

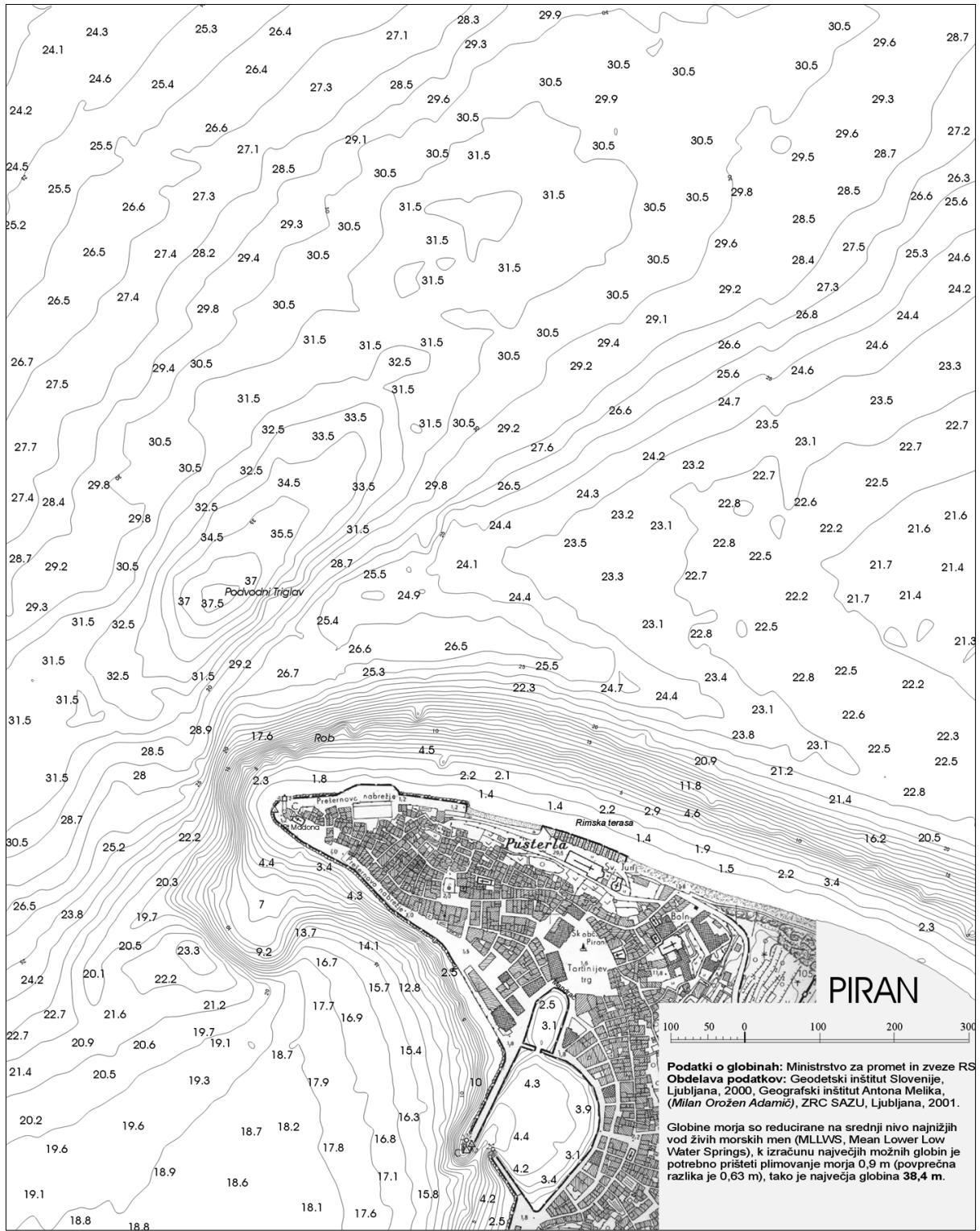

in je na najbolj izpostavljenem mestu pri rtu Madona tudi do 10 metrov visok. Ta skok, ki ga lahko primerjamo z ježo na obrečnem reliefu, to teraso, na skalnem dnu, $v$ tej globini sledimo ob celi Jadranski obali, pa tudi drugod po 
svetu. Posebej zanimiva je ta terasa na zunanjih, tektonsko pogojenih stenah Kornatskega otočja, kjer je na praktično navpični steni (podobni ostenju Črnega Kala) v tej globini, izrazita en meter široka polica. Videti je, da je ta stopnja posledica daljšega zadrževanja površine morja v tej legi. Ob apneniških obalah, še zlasti pa na odsekanih strmih podvodnih stenah, je zaradi večje odpornosti kamnine ta rob bolj opazen. V flišnem dnu, ki prevladuje ob slovenski obali, je rob veliko blažji, bolj zaobljen, vendar še vedno izrazit. Podvodna priobalna ravnica ali uravnan zgornji del terase je $\mathrm{v}$ flišu zaradi manjše odpornosti kamnine praviloma širši kot $\mathrm{v}$ apnencu. $\mathrm{V}$ notranjost zalivov, kjer je globina morja manjša, potone rob, oziroma je prekrit z recentnimi sedimentnimi nanosi. Thom (1973) je analiziral številna poročila in hipoteze o nihanju gladine morja. Mnogi raziskovalci so si danes enotni v mnenju, da je bila med zadnjo poledenitvijo (37.000 let) gladina morja nižja od današnje od 10 do 30 metrov in da je to ostanek takratne obalne črte. Ali je to res ostanek nekdanje gladine morja, oziroma je to rob o katerem govorimo, je še ne povsem rešeno vprašanje; treba bi ga bo ob slovenski obali še podrobneje proučiti in to domnevo tudi dokazati. $\mathrm{V}$ osrednjem in južnem Jadranu se na stenah apneniških obal $\mathrm{v}$ globini med 30 in $40 \mathrm{~m}$ pojavlja večje število jam, polic, teras, ali podobnih oblik, ki pa niso tako lepo in pravilno ohranjene kot terasa $\mathrm{v}$ globini $9 \pm 1 \mathrm{~m}$. Nesporno lahko govorimo o dveh terasah, mlajšem in starejšem nivoju morja. V Tržaškem zalivu te globlje terase ne najdemo, ker je morje danes preplitvo. Največje globine zaliva, kjer bi morda lahko naleteli nanjo, pa je zapolnjena s sedimenti in trdnejša skalna osnova $\mathrm{v}$ kateri bi lahko ugotovili to obliko, ni odkrita.

Poleg teh podvodnih teras je Šifrer (1965) opozoril še na več priobalnih uravnav. Na prvem mestu je zlasti pomembna znamenita tako imenovana "rimska" terasa. O njej govore tudi številna arheološka raziskovanja, kot na primer pri Žusterni (Izola), kjer je cela vrsta arheoloških ostankov, ki so danes približno $2 \mathrm{~m}$ pod morsko gladino. Ta terasa še daleč ni tako izstopajoča kot "rob", pa vendar jo lahko s pozornim opazovanjem zasledimo na mnogih krajih. Njena višina, oziroma višina stopnje, te terase je le redno večja od $0,5 \mathrm{~m}$. Ena od najbolj verjetnih razlag za to teraso je postopno grezanje vzhodne Jadranske obale in sklep, da je bila tu obalna črta v rimskem času dalj časa stabilna.

Melik (1960) govori tudi o vrtačah ali skalnih plitvinah v Tržaškem zalivu. Teh potapljači niso našli, če ne štejemo nekaj plitvin ob koncu Savudrijskega polotoka, ki sodijo k apneniški istrski obali ali pa odkritja najnovejših podvodnih izvirov (Žumer poročilo na tem zborovanju), ki pa bolj spominjajo na posebej oblikovane jame ali brezna ne pa na vrtače. Plitvine Grbo (Gobo), Jakomo (Jakovlja), Piranor in Buje pred rtom Savudrija v morju, ki je danes del Hrvaške, so v globini okrog $10 \mathrm{~m}$ in jih lahko uvrščamo v sistem ostankov 
že omenjene terase, oziroma potopljene priobalne ravnice. Brajde so povsem drugačno in razmeroma široko območje $\mathrm{v}$ osrednjem delu Tržaškega zaliva, 23 milje od obale $\mathrm{z}$ bolj grobim, peščenim dnom, brez jasne in ostre omejitve in v globini večinoma nekaj več kot $20 \mathrm{~m}$, z drugačnim ter svojskim podmorskim ekotopom.

$\mathrm{Na}$ apneniški obali polotoka Savudrija (od Kanegre proti rtu Savudrija) smo ob potapljanjih opazili tudi manjše, lahko z gotovostjo trdimo, občasne podvodne izvire sladke vode (vrulje). Ti še zdaleč niso tako izraziti, močni in stalni, kot jih poznamo na primer $\mathrm{v}$ krajih pod Velebitom. Morfološko pa so ti podvodni izviri nadaljevanje številnih kraških izvirov sladke vode, ki jih poznamo ob sečoveljskih solinah, pod Kaštelom in drugod v tem območju, kjer je stik apnencev s flišem ali pa akumulacijsko ravnico.

Na italijanski strani Tržaškega zaliva se uveljavljajo podobne značilnosti, s to razliko, da flišnih obal skoraj ni. Tudi tu je pod vodo več izvirov sladke vode. Pod Nabrežino in pri Miramarskem gradu je po vodo lepo viden naš že omenjen ob v globini okrog $9 \mathrm{~m}$. Pri Devinu so visoki in izredno lepi klifi v apnencu, ki spominjajo na klife, ki jih poznamo na primer na zunanji strani Kornatskega otočja. Tu se markantna tektonska in litološka ločnica, ki je pri nas vidna nad Črnim Kalom, spušča neposredno v morje.

Največja globina v slovenskem delu Tržaškega zaliva je $-37,5 \mathrm{~m}$, prav blizu obale pred rtom Madona pri Piranu. Spočetka so bolj za šalo, kot za res poimenovali Podvodni Triglav, sčasoma pa se je to ime prijelo. To je manjša ovalno oblikovana kotanja, ki je, vsaj videti je tako, nastala zaradi lokalno zmanjšane sedimentacije, ki so jo ustvarili lokalno močnejši morski tokovi ob izpostavljenem polotoku rtu Madona. Podobna in še malo globlja (- $40 \mathrm{~m})$ je kotanja ob rtu Savudrija, ki pa je že v Hrvaških vodah.

Potapljači ugotavljajo, da so morski tokovi ob izpostavljenih delih obale (rti) praviloma močnejši, zato so tu tudi največje globine Tržaškega zaliva. Zaradi razmeroma stalnih in lokalno močnejših morskih tokov prihaja na teh krajih do zmanjšanega odlaganja usedlin. Morski tok kakor reka nosi v vodi s seboj organske in anorganske delce. $\mathrm{Na}$ obrobju te kotanje nastajajo pravi grebeni - nasipi, ki se občasno premikajo in preoblikujejo. Naklon sedimentnega dna je tu $\mathrm{v}$ primerjavi $\mathrm{z}$ drugimi območji neobičajno velik. $\mathrm{Z}$ ekosonderjem (elektronsko napravo za merjenje globine na osnovi odboja zvoka) smo leta 1990 izmerili največjo globino $-37,25 \mathrm{~m}$. Podobne globine smo namerili tudi ob potapljanjih z običajnimi ročnimi globinomeri.

Natančnejše meritve Tržaškega zaliva so bile opravljene v sodelovanju z Oceanografskim uradom ameriške mornarice, obdelavo podatkov pa je za potrebe Urada za pomorstvo Ministrstvo za promet in zveze Republike Slovenije, ki je lastnik podatkov (1998). Obdelavo podmorskega dela podatkov in oblikovanje tega dela slike je izdelal Igor Klančnik Geodetski inštitut Slo- 
venije. Posebej podčrtavamo, da ti podatki niso primerni za navigacijo. Tako smo izdelali prvo (neuradno, informativno in delovno) podrobnejšo karto tega dela Tržaškega zaliva. Na karti so prikazane globine, ki so podane na decimeter natančno glede na standardno referenčno gladino morja in to je na srednje najnižje stanje morja (MLLWS Mean Lower Low Water Springs). Tako je na karti največja globina na $-37,5$, če pa $\mathrm{k}$ temu dodamo še $0,9 \mathrm{~m}$ razlike med plimo in oseko je lahko največja globina morja blizu $40 \mathrm{~m},-38,4 \mathrm{~m}$. Povprečna razlika med plimo in oseko je $\mathrm{v}$ tem delu morja $0,63 \mathrm{~m}$, lahko pa je ob izjemnih razmerah (nizek zračni tlak, močan jugo in narivanje vode iz južnega Jadrana) tudi $2,5 \mathrm{~m}$ ali več. Ta najnižja točka je približno $300 \mathrm{~m}$ od rta Madona v smeri $340^{\circ}$. Izobate so izdelane na osnovi hidrografskih meritev leta 1998 in dopolnilnih meritev leta 1999 in so razmaknjene za ekvidistanco $1 \mathrm{~m}$, vsaka peta izobata je označena tudi z globino. To najnižjo točko so potapljači označili z betonsko piramido iz časa vojne za Slovenijo (Nedelo, 11. 6. 2000). Na priloženem zemljevidu je lepo vidna ovalno izoblikovana kotanja $\mathrm{v}$ smeri severovzhod-jugozahod, na delu kjer je pod globino $-32 \mathrm{~m}$ njena izoblikovanost še posebej lepo vidna je ta kotanja dolga dobrih $640 \mathrm{~m}$ in široka približno $190 \mathrm{~m}$ in ima površino približno $10 \mathrm{ha}$. Na globini $-35 \mathrm{~m}$ je poligon velik le še 240 x $100 \mathrm{~m}$ in ima površino približno 2 ha. Le meter globlje na globini $-36 \mathrm{~m}$ pa je poligon izobate velik le še $110 \times 70 \mathrm{~m}$, ker je približno le še pol hektarja.

$\mathrm{Na}$ karti je tudi zelo lepo in izrazito viden »rob«, ježa, ki spremlja podvodno teraso okrog piranskega polotoka ter manj izstopajoča rimska terasa nad njim. Posebej zanimivo je območje prav okrog najbolj izpostavljenega dela na rta Madona, kjer so na globini okrog $9 \mathrm{~m}$ lepo vidni domnevni uravnani ostanki stare terase, ki se razteza pod vodo v območju od rta proti pristanišču. Zanimivo je tudi to, da smo tu pred leti našli zelo velike kolonije, edinih v tem delu morja znanih, kamenih koral (Cladochora sp.), ki pa jih danes zaradi antropogenih posegov skorajda ni več.

Zaradi tradicionalne in razmeroma intenzivne poselitve obal Tržaškega zaliva je razumljivo, da so obsežni deli neposrednega obalnega pasu močno preoblikovani z nasipi, pristanišči in podobnim. Urbanizacija neposrednega obalnega pasu in posegi $\mathrm{v}$ ta prostor so izredno intenzivni. Na mnogih krajih so umetno zasuli obalo in s takimi posegi še vedno nadaljujejo. To zelo zgovorno dokazuje fotografija v Melkovi knjigi o tem delu Slovenije (1960, str. 35), ki prikazuje klif med Piranom in Portorožem. Melik je ob sliki zapisal „S cesto in hišami je človek obrežno steno izločil iz funkcije“. Danes pa je na mestu, kjer ta slika še prikazuje morje, veliko morju iztrgano zemljišče na katerem je parkirišče za avtomobile. Vedno več obale se spreminja v "betonsko" obalo. Brez dvoma je to do neke mere nujno. Vendar moramo vprašati; Kje je ta meja? Iz takega razmišljanja že pred več kot dvema desetletjema so nastale prve zamisli in pobude za zavarovanje narave obalnega pasu in Tržaškega za- 
liva nasploh (Štirn 1970).

Prav ta majhnost, omejenost prostorskih - geomorfoloških - možnosti, je glavni problem stanja in prihodnjega razvoja tega območja. Na tem mahnem prostoru, si želimo ohraniti posebnosti naravne pokrajine, razvijati turizem, obenem pa imeti pristanišče za največje ladje. Prihaja do velikega navskrižja interesov rabe tal, ki pa se ga ne loteva dovolj odgovorno zaradi umanjkanja razmišljanj o strateških razvojnih načrtih.

\section{Literatura in viri:}

Bernot, F., 1990. Hidrogeografske značilnosti morja ob slovenski obali. Primorje. V: Zbornik 15. zborovanja slovenskih geografov, Portorož, 29-34.

Gams, I., 1970. Severna obala Strunjanskega polotoka. Proteus L. 33., št. 2, Ljubljana.

Geografski inštitut Antona Melika, meritve globinskih pasov, 1998.

Karničnik, I., 2000. Obdelava podatkov in oblikovanje slike pomorskega sveta na območju rta Madona pri Piranu. Geodetski inštitut Slovenije, Ljubljana.

Melik, A., 1960. Slovensko Primorje. Slovenija geografski opis II., opis slovenskih pokrajina, četrti zvezek, Ljubljana, 5-352.

Ministrstvo za promet in zveze Republike Slovenije, Urad za pomorstvo lastnik podatkov o globinah in izobatah (1998).

Orožen Adamič, M., 1980. Geografske značilnosti poplavnega sveta ob Dragonji in Drnici. Geografski zbornik 19., Ljubljana.

Orožen Adamič, M., 1990. Podvodni relief Tržaškega zaliva in varovanje naravne dediščine. Primorje. Zbornik 15. zborovanja slovenskih geografov, Portorož, 21-28.

Orožen Adamič, M., 1998. Podvodni Triglav. V: Perko, D., Orožen Adamič, M., (urednika) Slovenija - pokrajine in ljudje, Ljubljana, 291-293.

Orožen Adamič, M., 1998. Tržaški zaliv. V: Perko, D., Orožen Adamič, M., (urednika) Slovenija - pokrajine in ljudje, Ljubljana, 282-291.

Orožen Adamič, M., 1999. Podvodni Triglav. V: Perko, D., Orožen Adamič, M., (urednika) Slovenija - pokrajine in ljudje, Ljubljana, 291-293.

Orožen Adamič, M., 1999. Tržaški zaliv. V: Perko, D., Orožen Adamič, M., (urednika) Slovenija - pokrajine in ljudje, Ljubljana, 282-291.

Plut, D., 1980, Geografske značilnosti poplavnega sveta ob Rižani in Badaševici. Geografski zbornik 19., Ljubljana.

Primorje. Zbornik 15. zborovanja slovenskih geografov, 1990, Orožen Adamič, M., (urednik), Zveza geografskih društev Slovenije, Portorož, 303.

Ranke, U., 1974. Die Sedimente des Golfs von Piran. Mathematisch-Naturwieissennchaftlichen Fakultet der Georg August Univeritat, Gottingen. 
Radinja, D., 1990. Dimenzije Tržaškega zaliva in slovenskega morja ter njihov regionalni pomen. Primorje. V: Zbornik 15. zborovanja slovenskih geografov, Portorož, 13-20.

Radinja, D., 1990. Pokrajinske značilnosti Tržaškega zaliva in Koprskega Primorja. Primorje. V: Zbornik 15. zborovanja slovenskih geografov, Portorož, 7-12.

Svetličič, B., B., Križan, 1985. Slovenska obala - predstavitev naravne dediščine in naravovarstvena ocena stanja. Zavod SR Slovenije za varstvo naravne in kulturne dediščine, Medobčinski zavod za spomeniško varstvo Piran, Ljubljana - Piran.

Šifrer, J., 1965. Nova geomorfološka dognanja v Koprskem Primorju. Geografski zbornik 9., Ljubljana.

Štirn, J., 1970. Onesnaženje morja. Zelena knjiga o ogroženosti okolja v Sloveniji, str. 43-48, Ljubljana.

Titl, J., 1983, Območja morskih poplav v Koprskem Primorju. V: Naravne nesreče v Sloveniji. SAZU, Ljubljana.

Žumer, J., 1990, Recentni razvoj klifov Istrske Slovenije. "Geomorfologija in geoekologija" 5. znanstveno posvetovanje geomorfologov Jugoslavije, Krško.

\section{GEOMORPHOLOGICAL FEATURES OF THE BAY OF TRIESTE AND ITS SHORE}

\section{Summary}

The Bay of Trieste, the northernmost part of the Adriatic Sea, covers about $570 \mathrm{~km}^{2}$. This is only $0.4 \%$ of the Adriatic aquatorium. The Mediterranean Basin meets the Dinaric Alps here, and the Alps are also very close. The average depth of the bay is a mere 16 meters, and it is only deeper than 25 meters in a few places. The deepest point of the Bay of Trieste, 37.5 meters, is close to the shore off Cape Madona near Piran. This is a small oval-shaped basin formed due to locally smaller sedimentation caused by locally stronger currents. The volume of water in the Bay of Trieste is relatively small, about $11 \mathrm{~km}^{3}$, which is less than some larger lakes. All this is reflected in considerable shifts in water temperatures and recurrent, sometimes dramatic ecological changes. The central part of the sea floor (98\%) is composed of diverse marine sediments distinguished by the size of their particles. As a rule, the sediments are finer closer to the shore and have the properties of silt. The immediate littoral belt is composed of a solid "rocky" floor, except in the area of the sedi- 
mentary accumulation shore. The small and limited space options present the main problem for development. On one hand we wish to preserve the features of the natural landscape and develop tourism and related activities, but at the same time we want to have a harbour and its numerous accompanying activities. The conflict of interests is obvious since the geomorphological facts concretely limit the possibilities. 